\title{
Economics of Household Wind Turbine Grid-tied Systems for Five Wind Resource Levels and Alternative Grid Pricing Rates
}

\author{
Ahmad F. Ghaith, Francis M. Epplin* and R. Scott Frazier
}

Contact information:

Ahmad F. Ghaith

Department of Agricultural Economics

Oklahoma State University

Stillwater, OK 74078 USA

+1 508-801-1906

ahmad.ghaith@okstate.edu

*Corresponding author:

Francis M. Epplin

Department of Agricultural Economics

Oklahoma State University

Stillwater, OK 74078 USA

+1 405-744-6156

f.epplin@okstate.edu

R. Scott Frazier

Department of Biosystems and Agricultural Engineering

Oklahoma State University

Stillwater, OK 74078 USA

+1 405-744-5289

robert.frazier@okstate.edu 


\begin{abstract}
Households in the USA state of Oklahoma serviced by investor owned electric utilities that have smart meters may select to be charged based on either a traditional meter rate schedule, a smart meter schedule, or they may install a household grid-tied wind turbine and be subject to a different rate schedule. The objective of the research was to determine the economic consequences of installing microgeneration grid-tied wind turbine systems $(6 \mathrm{~kW} ; 10 \mathrm{~kW})$ given alternative pricing structures for households at five unique locations with different wind resources. Twenty years of hourly wind speed data, and hourly electricity use data for representative households, were obtained for each location. The annual household electricity cost among the five locations ranged from $\$ 894$ to $\$ 1,199$ for the smart meter rates and $\$ 870-\$ 1,191$ for the traditional meter rates. The estimated annual cost of $\$ 5,389$ for the least costly household grid-tied $6 \mathrm{~kW}$ wind turbine system, is five times greater than the annual cost of purchasing from the grid. If external consequences of electricity generation and distribution are ignored, given current and proposed rate structures and prices, household wind turbine electricity generation systems are not economically competitive in the region.
\end{abstract}

Key words: cost, grid-tied, renewable distributed generation, smart meter, wind energy, wind turbine

\title{
1. Introduction
}

Prior to the introduction of rural electrification, windmills used to pump water were common in rural areas of the USA Great Plains. Windmills are still common in remote areas that do not have access to the grid. Wind turbines for electricity microgeneration are manufactured by 
private companies, and advertised for sale to rural on-grid households in the region. The economics of grid-tied household wind turbine electricity generation systems for the region have not been fully explored. Economics depends on a number of factors for which data are readily available such as investment cost, price of grid electricity, and type of metering system. However, a comprehensive economic analysis also requires information that is more difficult to obtain, such as hourly information regarding site-specific wind speed.

The USA state of Oklahoma is located in the southern Great Plains. The unique Oklahoma Mesonet weather system has recorded 20 years of hourly wind data for more than 100 sites across the state. The geography and climate of the state is quite diverse ranging from an elevation of $110 \mathrm{~m}, 132 \mathrm{~cm}$ of annual rainfall, and average wind speed of $2.8 \mathrm{~m} / \mathrm{s}$ at Idabel in the southeast, to an elevation of $1,267 \mathrm{~m}, 46 \mathrm{~cm}$ of annual rainfall, and average wind speed of 5.5 $\mathrm{m} / \mathrm{s}$ at Boise City in the northwest [1]. The western half of Oklahoma is located in America's wind corridor [2]. The prevalence of wind inspired the line “...where the wind comes sweeping down the plain..." in the musical play named after the state [3]. Seventeen percent of the electricity generated in the state is produced by large commercial wind turbines [4]. Development of the commercial wind turbine sector has been aided by a state subsidy of $\$ 0.005$ per $\mathrm{kWh}$ produced by systems with rated production capacity of one megawatt or greater [5] and by a federal investment tax credit of $30 \%$ [5].

Household wind systems are not common in the state. A 2009 census survey found that 20 Oklahoma farms reported an installed wind turbine for on-farm use [6]. There are about 80,000 farms in Oklahoma [7]. Thus, these data suggest that $0.025 \%$ of Oklahoma farms have a farm-based wind turbine system. Some Oklahoma farms purchase electricity from rural electric cooperatives. However, much of rural Oklahoma is serviced by investor-owned electric utilities 
that are natural monopolies. In the USA, rates charged by investor-owned public utilities are regulated by state authorities. The Constitution of the State of Oklahoma provides the Oklahoma Corporation Commission (OCC) with the authority and responsibility to supervise, regulate, and control Oklahoma investor-owned electric utilities [8]. The OCC is charged with the responsibility of insuring adequate service, preventing unfair charges to the public, protecting the utilities from unreasonable demands, and enabling a fair return to investors [9].

Electric meters measure the quantity of electricity removed from the electrical grid at the metered site. Traditional (accumulation) meters measure total consumption and do not provide information of when the energy was used during the time period of interest [10]. Historically, rates approved by the OCC followed from the technical constraint imposed by traditional meters and billing systems. OCC rates approved for one utility to apply to farms and households with traditional meters are shown as alternative I in Appendix A [11]. A fixed price per kilowatt-hour $(\mathrm{kWh})$ is charged independent of the time of day the electricity is consumed. The regulated prices are assumed to be greater than the marginal cost at off-peak load times, and lower than the marginal cost at peak load times.

Introduction of alternative pricing systems to more nearly align prices with marginal costs has been limited by the prevalence of traditional meters $[12,13,14]$. Smart meters provide a way of measuring site-specific information, allowing regulators to permit utility companies to charge different rates based on time of use. Different rates for different hours of the day may be used to incentivize reductions in use during traditional peak time periods. Theoretically, smart meters that enable two-way communications between the utility and their customers, facilitate real-time monitoring of electricity flows, and enhance both the technical and allocative efficiency of electricity markets. Smart meters enable the utility to charge different rates for 
different times of the day. Alternative II rates as shown in Appendix A have been approved for one utility by the OCC [11] for Oklahoma users that have smart meters [15]. Customers that have smart meters may select either the alternative I or alternative II pricing system subject to 12 month contracts that may be renewed each year.

Figure 1 illustrates marginal costs for hypothetical base load and peak load situations. Base load is assumed to be generated by the lowest cost fuel source, which, in Oklahoma, if externalities including the consequences of carbon released into the atmosphere are ignored, is coal. During hot summer afternoons, for example between 2 p.m. and 7 p.m., when electric powered air conditioners are operating near capacity, electricity use peaks [11]. During the peakload period, use may exceed base load plant capacity. In Oklahoma, most requirements in excess of base load are generated by natural gas powered plants. If the external consequences are ignored, the marginal cost of using natural gas is greater than the marginal cost of using coal (Figure 1). For example, in October 2015 the cost of producing one $\mathrm{kWh}$ from coal was $61 \%$ as much as the cost of producing one $\mathrm{kWh}$ from natural gas [16]. 


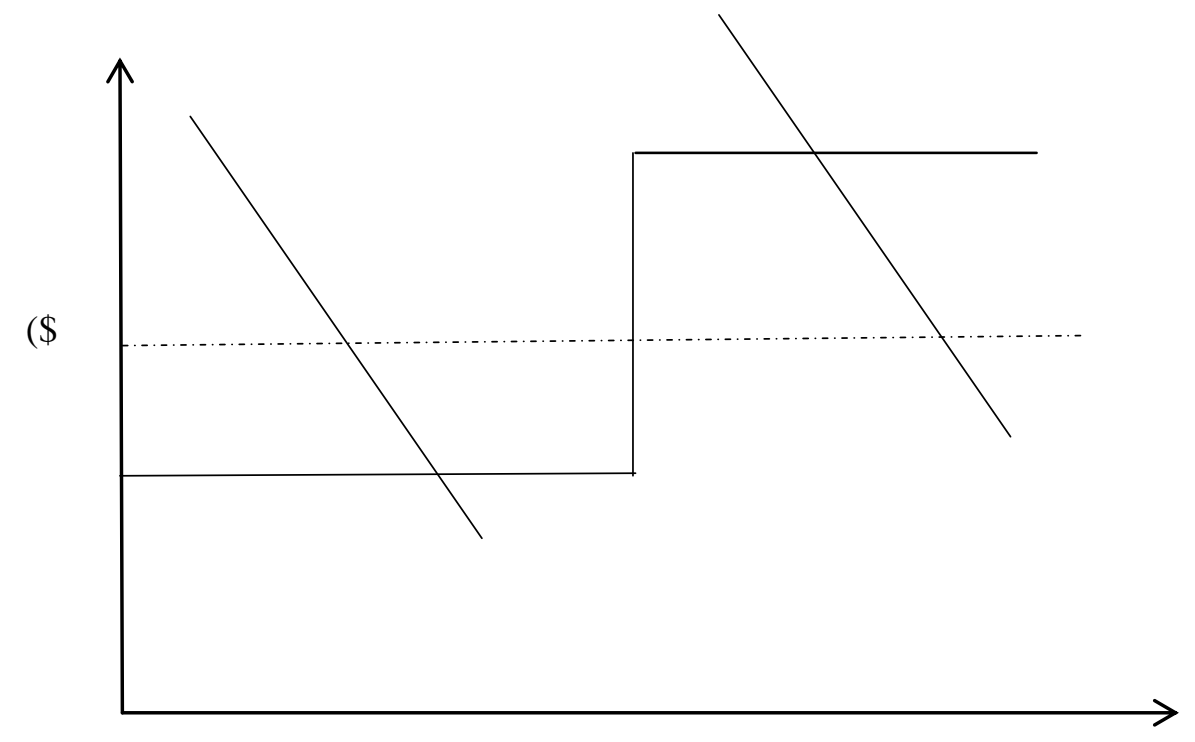

\section{Figure 1: Household Electricity Marginal Cost, Peak Demand, and Off-Peak Demand}

The economics of a grid-tied household wind turbine microgeneration system depends in part on the grid electricity pricing structure in effect for the household. Prior to 2014 the OCC required Oklahoma utilities to make net metering available to all customer classes [17]. For net metering scenarios, each rate block during a billing period (assumed to be one month) is treated separately. The consumer is charged for the difference between the total electricity removed from the grid during the block and the total electricity provided to the grid during that block for the month. However, the consumer is not compensated if household production during a block exceeds household use during the same block. The household is charged for the net electricity withdrawn from the grid, that is, the total removed minus the total provided to the grid during the billing period. However, to participate in net metering, the household could be required to provide net excess generation to the grid at no charge [18]. Smart meter (Time of Use (TOU)) 
net-metering charges to the household are determined by each block (on-peak and off-peak) for each billing period (monthly).

There are several issues associated with net metering that influence aggregate economic efficiency. If households are reimbursed at the full retail rate, the net effect is that on average the utility will pay more for electricity from net metering households than for electricity from power plants. Net metering requires that additional investments be made by the utility in equipment required to safely manage the reliability of the grid when electricity produced by an individual household is sent to the grid [19]. In addition, since wind turbines depend on the quantity of wind, they cannot be relied on to be available during peak load periods. For these reasons, representatives of electric utility companies contend that with net metering, households that have microgeneration grid-tied systems would be subsidized by households that do not. In response to these issues, in 2014, the Oklahoma legislature passed and the Governor signed a bill enabling substantial changes in the way grid-tied household microgeneration systems in Oklahoma are charged for electricity purchased from the grid [20].

The 2014 legislation enables Oklahoma utilities regulated by the OCC to submit unique rate structures for households that have a microgeneration grid-tied system. One major utility has proposed the alternative III rates as shown in Appendix A that would be applicable for households with Renewable Distributed Generation (RDG) grid-tied (microgeneration) systems. RDG customers would be assessed a greater monthly base charge ( $\$ 18$ rather than $\$ 13$ ) than traditional and smart meter customers, plus a charge based on peak withdrawal from the grid. This peak (maximum demand) charge would be determined based on the maximum 15-minute period withdrawal from the grid during the billing period (assumed to be one month). For example, for a month with 30 days, the utility would determine the quarter hour from among the 
2,880 15-minute periods during the month with the maximum usage. The quantity of electricity (kWh) withdrawn from the grid during that quarter hour would then be multiplied by the $\$ 2.68$ proposed rate $[11,21]$. In addition, for weekday usage between 2 p.m. and 7 p.m. during the months of June through October, RDG customers would be charged $\$ 0.173 / \mathrm{kWh}$. This is $23.6 \%$ greater than the smart meter rate for this time segment.

Some research has been conducted to evaluate household microgeneration systems [2229]. For example, Elhadidy [22] evaluated the performance of hybrid wind-solar plus battery storage systems with Diesel back-up to satisfy a specific level of annual electricity requirements. Elkinton et al. [23] sized hybrid wind-solar grid-tied systems required for residential housing developments in five different locations to fully compensate the grid for electricity withdrawn during a year. Darbali-Zamora et al. [24] and Li et al. [25] also estimated the feasibility of hybrid wind-solar systems. Iqbal [26], Grieser et al. [27], Mostafaeipour et al. [28], and Dalabeeh [29] have studied the technical and economic feasibility of wind turbine systems.

Since public utilities may charge different rates for electricity withdrawn from the grid depending on hour of use and month of year, a comprehensive economic analysis of grid-tied household wind systems requires detailed wind speed data. One limitation of the prior studies [22-29] is that hourly wind speed data for a number of years was not available for the location under study. Thus, the analysis was limited to either expected annual, monthly, or daily wind speeds. This limitation reduced the ability of the models to capture fully the variability in electricity production. A second limitation is that household consumption also varies depending on hour of use and month of year. Prior studies have used accumulated profile load estimates and have only matched crudely time of production with time of use. A third limitation of prior 
research is that an average monthly price was assumed for electricity purchased from the grid. This shortcoming fails to account for the economic consequences of peak load pricing schemes. This research builds on prior research [22-29] and extends it in several important aspects. First, the Mesonet system provides 20 years of hourly wind speed data for each of the five locations. This enables the production of estimates of the electricity generated by each system at each of the five locations for each hour of each month. This is important because electricity rates charged by public utilities differ depending on month and hour. Second, in addition to differences in wind speed among hours and months, the modeling system accounts for differences in air density when estimating the productivity of each turbine, at each of the five locations. Third, representative households as defined from census data for structure size and characteristics and number of occupants were defined for each of the five locations. Estimates of household electricity consumption by these representative households for each hour for each month for each location were obtained from simulations by the USA Department of Energy. These simulations find that each location has a unique average load profile resulting from differences in climate and household characteristics. Fourth, cost estimates are produced for three different types of rate structures including a smart meter rate schedule that has seven different rates depending on hour of the day, month of the year, and quantity of household use.

The overall objective of the research is to determine the economic consequences of installing microgeneration grid-tied wind turbine systems $(6 \mathrm{~kW} ; 10 \mathrm{~kW})$ given alternative pricing structures (traditional accumulation meter; smart meter; proposed RDG; each with and without net metering) for households at five unique locations in Oklahoma (Boise City; Miami; Shawnee; Hollis; Idabel) that have substantially different wind resources. The specific objectives are to determine the annual cost of electricity for the five case study households based on: 
a) traditional meter rates for grid-only electricity;

b) smart meter rates for grid-only electricity;

c) proposed RDG rates for a $6 \mathrm{~kW}$ wind turbine grid-tied system;

d) proposed RDG rates for a $10 \mathrm{~kW}$ wind turbine grid-tied system;

e) traditional meter rates for a $6 \mathrm{~kW}$ wind turbine grid-tied system with net metering;

f) traditional meter rates for a $10 \mathrm{~kW}$ wind turbine grid-tied system with net metering;

g) smart meter rates for a $6 \mathrm{~kW}$ wind turbine grid-tied system with net metering;

h) smart meter rates for a $10 \mathrm{~kW}$ wind turbine grid-tied system with net metering;

i) proposed $\mathrm{RDG}$ rates for a $6 \mathrm{~kW}$ wind turbine grid-tied system with net metering;

j) proposed RDG rates for a $10 \mathrm{~kW}$ wind turbine grid-tied system with net metering;

In addition, the purchase price at which each of the wind turbine systems breaks even with the grid-only system will be determined. The findings will enable a determination of the economic value of the microgeneration systems for each of the locations.

Since wind resources differ substantially across the state, five sites were chosen: Boise City in the Northwest, Miami in the Northeast, Shawnee in the Central, Hollis in the Southwest, and Idabel in the Southeast, as shown in Figure 2. 


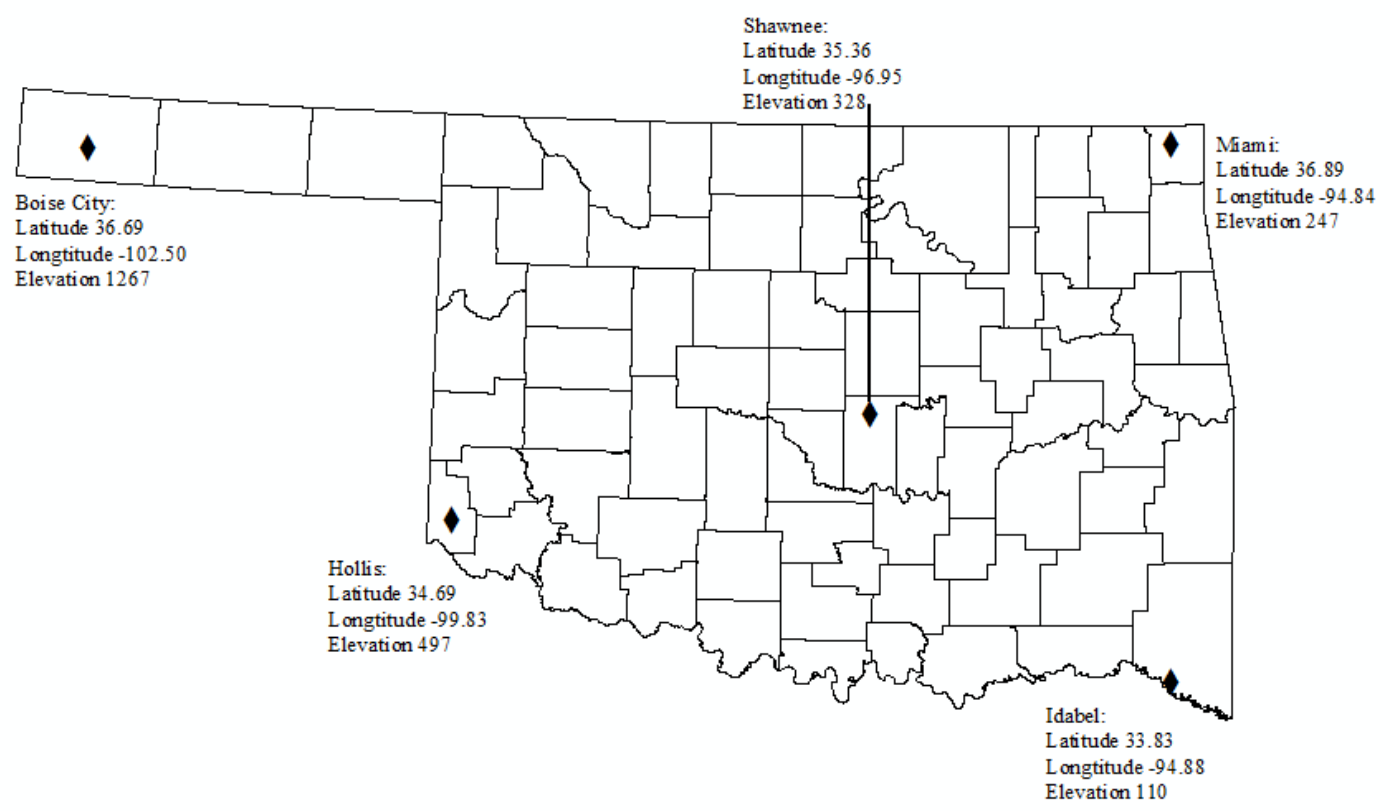

Figure 2: Location of the Oklahoma Selected Sites for the Study

\section{Conceptual Framework}

The economics of a household grid-tied wind turbine system depends on the cost of owning and operating the system, the amount and timing of electricity produced by the system, the quantity and timing of electricity required by the household, and the cost of purchasing electricity from the grid.

\subsection{Estimation of Wind Turbine Power Output}

Theoretically, the power output produced by wind turbines depends on the rotor sweep area, air density, mechanical efficiency (proportion of wind power transferred into electricity), and wind speed [30]. At a certain level of wind speed, the cut-in wind speed, the wind turbine starts to produce electricity. Electricity output is effectively zero for wind speeds less than cut-in. Over a range of wind speeds, electricity output increases at an increasing rate and may be described by a cubic function [30]. To prevent damage from high wind speeds, wind turbines are 
equipped with an automatic furling system. Over a range of wind speeds, electricity production continues to increase but at a decreasing rate to a level at which power output plateaus. This range may be described by a quadratic function. Conceptual representation of the entire power curve can be accomplished by splicing a cubic function [29] to a quadratic function to a plateau as described in equation 1 .

The electricity output $(\mathrm{kWh})$ from a wind turbine can be described as:

$P=\left[\begin{array}{cc}0 & V_{i}<V_{\text {Cut-in }}, V>V_{0} \\ K C_{p} \frac{1}{2} \rho A V^{3} & V_{\text {Cut-in }} \leq V \leq V_{r} \\ \alpha_{0}+\alpha_{1} V+\alpha_{2} V^{2} & V_{r}<V<V_{p} \\ P_{r} & V_{p} \leq V \leq V_{0}\end{array}\right.$

where, $P$ is the power output $(\mathrm{kW}), P_{r}$ is the plateau output level $(\mathrm{kW}), K$ is equal to 0.001 , which is a constant to transfer the power output from $\mathrm{W}$ to $\mathrm{kW}, C_{p}$ is the mechanical efficiency coefficient, $\rho$ is the air density $\left(\mathrm{kg} / \mathrm{m}^{3}\right), A$ is the rotor sweep area $\left(\mathrm{m}^{2}\right), V$ is wind speed $(\mathrm{m} / \mathrm{s})$, $V_{C u t-i n}$ is the minimal wind speed required to initiate production, $V_{r}$ is the wind speed at which production begins to increase at a decreasing rate, $V_{p}$ is the wind speed at which production is at a plateau level, $V_{0}$ is the wind speed at which production is assumed to be zero (high wind speeds at which the turbine is braked to prevent damage), $\alpha_{0}$ is the constant of the quadratic function, $\alpha_{1}$ is the coefficient for the linear term, and $\alpha_{2}$ is the coefficient for the quadratic term.

\subsection{Estimation of the Annual Electricity Cost for Each Alternative}

For a household serviced by a traditional meter, the annual cost of electricity is calculated as:

$$
E C T M=\sum_{j=1}^{12} B C_{j}+\sum_{j=1}^{12} D_{j} \operatorname{ERTM}_{j}\left(\sum_{i=1}^{24} G_{i j}\right)
$$

where, ECTM is the annual electricity cost for the household using the traditional meter, ERTM is the OCC rate for the traditional meter rate during the $j^{\text {th }}$ month, $G_{i j}$ is the electricity used 
(kWh) in the $i^{\text {th }}$ hour, during the $j^{\text {th }}$ month where $i=1,2, \ldots, 24, D_{j}$ is the number days of the $j^{\text {th }}$ month, if $j=1,3,5,7,8,10$, or 12 then $D_{j}=31$, if $j=4,6,9$, or 11 then $D_{j}=30$, and if $j=2$ then $D_{j}=28$, and $B C_{j}$ is a fixed base charge per month independent of electricity use.

For a household serviced by a smart meter, the annual cost of electricity is calculated as:

$$
E C S M=\sum_{j=1}^{12} B C_{j}+\sum_{j=1}^{12} D_{j}\left(\sum_{i=1}^{24} \operatorname{ERSM}_{i j} G_{i j}\right)
$$

where, ECSM is the annual electricity cost for the household using the smart meter rate, $E R S M_{i j}$ is the OCC rate for the smart meter rate in the $i^{\text {th }}$ hour during the $j^{\text {th }}$ month.

The annual charge for electricity withdrawn from the grid and for the opportunity of having a grid tied wind turbine based on the proposed rate schedule would be:

$$
E C G T=\sum_{j=1}^{12} B C G T_{j}+\sum_{j=1}^{12}\left(\frac{H_{j}}{4}\right) 2.68+\sum_{j=1}^{12} D_{j}\left(\sum_{i=1}^{24} E R G T_{i j} N G_{i j}\right)
$$

where, ECGT is the annual electricity cost for the household with the grid-tied RDG rate, $B C G T_{j}$ is the base charge for a grid tied system, $H_{j}$ is the quantity $(\mathrm{kWh})$ withdrawn from the grid during the highest consumption hour of electricity withdrawn in the $j^{\text {th }}$ month, $E R G T_{i j}$ is the proposed RDG rate for the $i^{\text {th }}$ hour during the $j^{\text {th }}$ month, $N G_{i j}(\mathrm{kWh})$ is the net electricity used by households after using the power output produced by the wind turbine, where $N G_{i j} \geq 0$.

The annual charge for electricity withdrawn from the grid and for the opportunity of having a grid-tied wind turbine based on the traditional meter rate schedule with net metering would be:

$$
E C T M N=\sum_{j=1}^{12} B C_{j}+\sum_{j=1}^{12} D_{j} \operatorname{ERTM}_{j}\left(\sum_{i=1}^{24} G_{i j}\right)-\sum_{j=1}^{12} D_{j} \operatorname{ERTM}_{j}\left(\sum_{i=1}^{24} P_{i j}\right)
$$

where, ECTMN is the annual electricity cost for the household with the grid-tied RDG system using the traditional meter rates with the opportunity of net metering, and $P_{i j}(\mathrm{kWh})$ is the excess power output produced by the wind turbine in the $i^{\text {th }}$ hour, during the $j^{\text {th }}$ month. 
The annual charge for electricity withdrawn from the grid and for the opportunity of having a grid tied wind turbine based on the smart meter rate schedule with net metering would be:

$$
\operatorname{ECSMN}=\sum_{j=1}^{12} B C_{j}+\sum_{j=1}^{12} D_{j}\left(\sum_{i=1}^{24} E R S M_{i j} G_{i j}\right)-\sum_{j=1}^{12} D_{j}\left(\sum_{i=1}^{24} E R S M_{i j} P_{i j}\right)
$$

where, ECSMN is the annual electricity cost for the household with the grid tied RDG system using the smart meter rates with the opportunity of net metering.

The annual charge for electricity withdrawn from the grid and for the opportunity of having a grid tied wind turbine based on the proposed rate schedule with net metering would be:

$$
\begin{aligned}
& E C G T N= \\
& \sum_{j=1}^{12} B C G T_{j}+\sum_{j=1}^{12}\left(\frac{H_{j}}{4}\right) 2.68+\sum_{j=1}^{12} D_{j}\left(\sum_{i=1}^{24} E R G T_{i j} G_{i j}\right)- \\
& \sum_{j=1}^{12} D_{j}\left(\sum_{i=1}^{24} E R G T_{i j} P_{i j}\right)
\end{aligned}
$$

where, ECGTN is the annual electricity cost for the household with the grid tied RDG system using the proposed rates with the opportunity of net metering.

\subsection{Estimation of Wind Turbine Breakeven Price}

To determine the purchase price at which an investment in a wind turbine system would break even with grid only electricity, the difference between the present value of the cost before and after adopting the wind turbines is determined.

For the households paying traditional meter rates, the breakeven price is:

$$
B E T M=\frac{\sum_{t=1}^{20} E_{C T M_{t}}}{(1+r)^{t}}-\frac{\sum_{t=1}^{20} E C G T N_{t}+\sum_{t=1}^{20} V C_{t}}{(1+r)^{t}}
$$

where, $B E T M$ is the wind turbine breakeven price for traditional meter rate households, and $V C_{t}$ is the variable cost of the wind turbines at the $t^{\text {th }}$ years, $t=1,2, \ldots, 20$.

For the households who are charged smart meter rates, the breakeven price is: 


$$
B E S M=\frac{\sum_{t=1}^{20} E C S M_{t}}{(1+r)^{t}}-\frac{\left.\sum_{t=1}^{20} E C G T N_{t}+\sum_{t=1}^{20} V C_{t}\right)}{(1+r)^{t}}
$$

where, BESM is the wind turbine breakeven price for smart meter rate households.

\subsection{Estimation of the Annual Cost of the Wind Turbine}

The following equations were used to estimate the annual cost of the RDG systems [31]

Depreciation $\left(\frac{\$}{\text { year }}\right)=\frac{(\text { Purchase Price }- \text { Salvage Value })}{\text { Years of Life }}$,

Interest $\left(\frac{\$}{\text { year }}\right)=\frac{\text { Purchase Price }+ \text { Salvage Value }}{2} *$ Real Interest Rate,

Insurance $\left(\frac{\$}{\text { year }}\right)=\frac{\text { Purchase Price }+ \text { Salvage Value }}{2} *$ Insurance Rate, and

Property Tax $\left(\frac{\$}{\text { year }}\right)=$ Average System Price $*$ Assessed Rate $* 0.086$.

\section{Data and Method}

\subsection{Hourly Weather Data}

Hourly weather data were obtained from the Oklahoma Mesonet. The Mesonet consists of 120 automated weather stations. Many of these stations have been collecting precise weather data since 1994. Data collected includes wind speed (m/s), air pressure (inches of mercury), air temperature $\left(\mathrm{F}^{\mathrm{o}}\right)$, relative humidity $(\%)$, and solar radiation $\left(\mathrm{watt} / \mathrm{m}^{2}\right)$. For the present study, average values of power output for each of 24 hours for each of 12 months were obtained, as the wind turbine power output is a function of wind speed. For example, the power output estimate for hour one for January is the mean of 620 observed values; 31 days of hour one observations for each of 20 years. These data may be used to estimate the expected power output from wind turbine systems at a specific site for each hour of the day for each month.

\subsection{Residential hourly electricity data}

The residential hourly electricity profiles for Boise City, Hollis, Shawnee, Miami, and Idabel, Oklahoma households were obtained from the U.S. Department of Energy [32]. 
Simulated load profiles are averages over many households. The characteristics of the house and household to be modeled are reported in Table 1.

Table 1: Characteristics of the House and Household being Modeled

\section{Characteristics}

\section{Description/Unit}

Mixed Humid $\dagger \quad$ Mixed Dry

\begin{tabular}{lcc}
\hline Building Fuel Types & & \\
Space Heating & Natural Gas & Natural Gas \\
Air Conditioning & Yes & Yes \\
Water Heating & Natural Gas & Natural Gas \\
Building Structure Types & & \\
Total Size & $236.5\left(\mathrm{~m}^{2}\right)$ & $185.8\left(\mathrm{~m}^{2}\right)$ \\
Number of Stories/Level & $1 \mathrm{Story}$ & $1 \mathrm{Story}$ \\
Bedrooms & 3 & 3 \\
Bathrooms & 1 & 2 \\
Basement & No & No \\
Type of Glass in Windows & Double-pane Glass & Single-pane Glass \\
\hline
\end{tabular}

Source: National Renewable Energy Laboratory

$\dagger$ Hollis, Shawnee, Miami, and Idabel are included in the mixed humid region. Boise City is included in the mixed dry region.

\subsection{Wind Turbines}

The American Wind Energy Association (AWEA) has adopted a set of household scale wind turbine performance standards [33]. They have established a common system for testing and reporting wind turbine energy performance. The Small Wind Certification Council (SWCC) is an independent certification agency that verifies and certifies test results relative to the AWEA standard [34]. SWCC has certified seven wind turbines. Information for each of these seven systems is reported in Table 2. The SWCC certified systems range from 1.5 to $10.4 \mathrm{~kW}$ rated at $11 \mathrm{~m} / \mathrm{s}$. The total cost divided by the rated annual energy output is approximately $\$ 5 / \mathrm{kW}$ for the four larger machines that range from 5.2 to $10.4 \mathrm{~kW}$. The cost per $\mathrm{kW}$ is substantially greater for 
the smaller ( 1.5 to $2.5 \mathrm{~kW}$ ) systems. Given the higher cost per $\mathrm{kW}$ for the smaller systems and given that the AWAE recommends a minimum size of $5 \mathrm{~kW}$ for a USA household, the three smaller systems were not considered. Since both the Excel 6 and Excel 10 are marketed in the region of the study, they were selected for modeling.

Table 2: List of available wind turbines in USA and their cost

\begin{tabular}{|c|c|c|c|c|c|c|c|}
\hline Applicant & Turbine & $\begin{array}{c}\text { SWCC } \\
\text { Certification } \\
\text { Type }\end{array}$ & $\begin{array}{c}\text { AWEA } \\
\text { Rated } \\
\text { Annual } \\
\text { Energy } \\
\text { (kWh) }\end{array}$ & $\begin{array}{c}\text { AWEA } \\
\text { Rated } \\
\text { Power } \\
\text { at 11 } \\
\text { m/s } \\
(\mathrm{kW})\end{array}$ & $\begin{array}{c}\text { Peak } \\
\text { Power }\end{array}$ & $\begin{array}{c}\text { Total } \\
\text { Cost } \$\end{array}$ & $\begin{array}{c}\text { Annual } \\
\text { Average } \\
\text { Cost } \\
\$ / \mathbf{k W h} \\
\dagger\end{array}$ \\
\hline $\begin{array}{l}\text { Bergey } \\
\text { Windpower Co. }\end{array}$ & Excel 10 & $\begin{array}{l}\text { AWEA 9.1- } \\
2009\end{array}$ & $13,800 \mathrm{kWh}$ & 8.9 & $\begin{array}{l}12.6 \mathrm{~kW} \\
@ 16.5 \\
\mathrm{~m} / \mathrm{s}\end{array}$ & $65,000^{*}$ & 4.7 \\
\hline $\begin{array}{l}\text { Xzeres Wind } \\
\text { Corporation }\end{array}$ & 442SR & $\begin{array}{l}\text { AWEA 9.1- } \\
2009\end{array}$ & $16,700 \mathrm{kWh}$ & 10.4 & $\begin{array}{l}11.3 \mathrm{~kW} \\
@ 12.0 \\
\mathrm{~m} / \mathrm{s}\end{array}$ & $83,000 * *$ & 5.0 \\
\hline $\begin{array}{l}\text { Kingspan } \\
\text { Environmental }\end{array}$ & KW6 & $\begin{array}{l}\text { AWEA 9.1- } \\
2009\end{array}$ & $8,950 \mathrm{kWh}$ & 5.2 & $\begin{array}{l}6.1 \mathrm{~kW} @ \\
17.0 \mathrm{~m} / \mathrm{s}\end{array}$ & $45,000^{*}$ & 5.0 \\
\hline $\begin{array}{l}\text { Bergey } \\
\text { Windpower Co. }\end{array}$ & Excel 6 & $\begin{array}{l}\text { AWEA 9.1- } \\
2009\end{array}$ & $9,920 \mathrm{kWh}$ & 5.5 & $\begin{array}{l}6.7 \mathrm{~kW} @ \\
16.0 \mathrm{~m} / \mathrm{s}\end{array}$ & $55,000 * *$ & 5.5 \\
\hline $\begin{array}{l}\text { Xzeres Wind } \\
\text { Corporation }\end{array}$ & $\begin{array}{l}\text { Skystream } \\
3.7\end{array}$ & $\begin{array}{l}\text { AWEA 9.1- } \\
2009\end{array}$ & $3,420 \mathrm{kWh}$ & 2.1 & $\begin{array}{l}2.4 \mathrm{~kW} @ \\
14.0 \mathrm{~m} / \mathrm{s}\end{array}$ & $23,800 * *$ & 7.0 \\
\hline Pika Energy & $\mathrm{T} 701$ & $\begin{array}{l}\text { AWEA 9.1- } \\
2009\end{array}$ & $2,420 \mathrm{kWh}$ & 1.5 & $\begin{array}{l}1.7 \mathrm{~kW} @ \\
13.5 \mathrm{~m} / \mathrm{s}\end{array}$ & $22,350 * *$ & 9.2 \\
\hline $\begin{array}{l}\text { Eveready } \\
\text { Diversified } \\
\text { Products (Pty) Ltd. }\end{array}$ & $\begin{array}{l}\text { Kestrel } \\
\text { e400nb }\end{array}$ & $\begin{array}{l}\text { AWEA 9.1- } \\
2009\end{array}$ & $3,930 \mathrm{kWh}$ & 2.5 & $\begin{array}{l}3.0 \mathrm{~kW} @ \\
19.5 \mathrm{~m} / \mathrm{s}\end{array}$ & - & \\
\hline
\end{tabular}

* Source: personal contact with Bergey Windpower Co.

** Source: [35]

$\dagger$ Annual Average Cost $=$ Total Cost / AWEA Rated Annual Energy

The modeled wind turbine systems are Excel $10(10 \mathrm{~kW})$ and Excel $6(6 \mathrm{~kW})$, with $7 \mathrm{~m}$ and $6.2 \mathrm{~m}$ rotor diameter, respectively. The installed cost of the $10 \mathrm{~kW}$ machine is estimated to be $\$ 65,000$ ( $\$ 32,000$ for the turbine; $\$ 15,000$ for the $30.5 \mathrm{~m}$ tower; $\$ 15,000$ for installation and foundation preparation; $\$ 3,000$ for permits). The installed cost for the $6 \mathrm{~kW}$ system is estimated to be $\$ 55,000$ ( $\$ 22,000$ for the turbine with other costs the same as for the $10 \mathrm{~kW})$. 
The Bergey Windpower Company [36] that manufactures both modeled turbines recommends that purchasers expect a useful life of no more than 20 years. Several studies have cautioned against extending the expected life of household wind turbines beyond 20 years. For example, Staffell and Green [37] found that expected power output declines with wear, and over a 20-year period, users could expect a 12\% reduction. Rademakers et al. [38] report that after 20 years a user could expect to incur repair costs in excess of $60 \%$ of the original investment costs. Hence, the useful life of the turbines is assumed to be 20 years, with no maintenance cost the first five years and maintenance cost in years 6-10 of \$250 annually; years 11-15 of $\$ 500$ annually; and years 16-20 of $\$ 1000$ annually. Both systems are equipped with automatic furling systems that enable power output over a range of wind speeds while protecting the integrity of the equipment [36].

The SWCC test report includes the power curve; the power $(\mathrm{kW})$ output response as a function of wind speed, as shown in Figure 3. The power curve is reported over the range of wind speeds from 0.5 to $20.5 \mathrm{~m} / \mathrm{s}$ for the Excel 10 [39] and from 0.5 to $18.5 \mathrm{~m} / \mathrm{s}$ for the Excel 6 [40]. For the case study locations, the maximum wind speed across all hour-month combinations was $23 \mathrm{~m} / \mathrm{s}$. Power output from the Excel 10 tracks the theoretical cubic power output curve from 0.5 to $11 \mathrm{~m} / \mathrm{s}$. Output continues to increase at a decreasing rate from 11 to $15 \mathrm{~m} / \mathrm{s}$ for Excel 10 and from 9 to 14 m/s for Excel 6 after which output plateaus. For Excel 10 and Excel 6 after $20.5 \mathrm{~m} / \mathrm{s}$ and $18.5 \mathrm{~m} / \mathrm{s}$ wind speed, respectively, the wind turbine will shut down to prevent damage. 

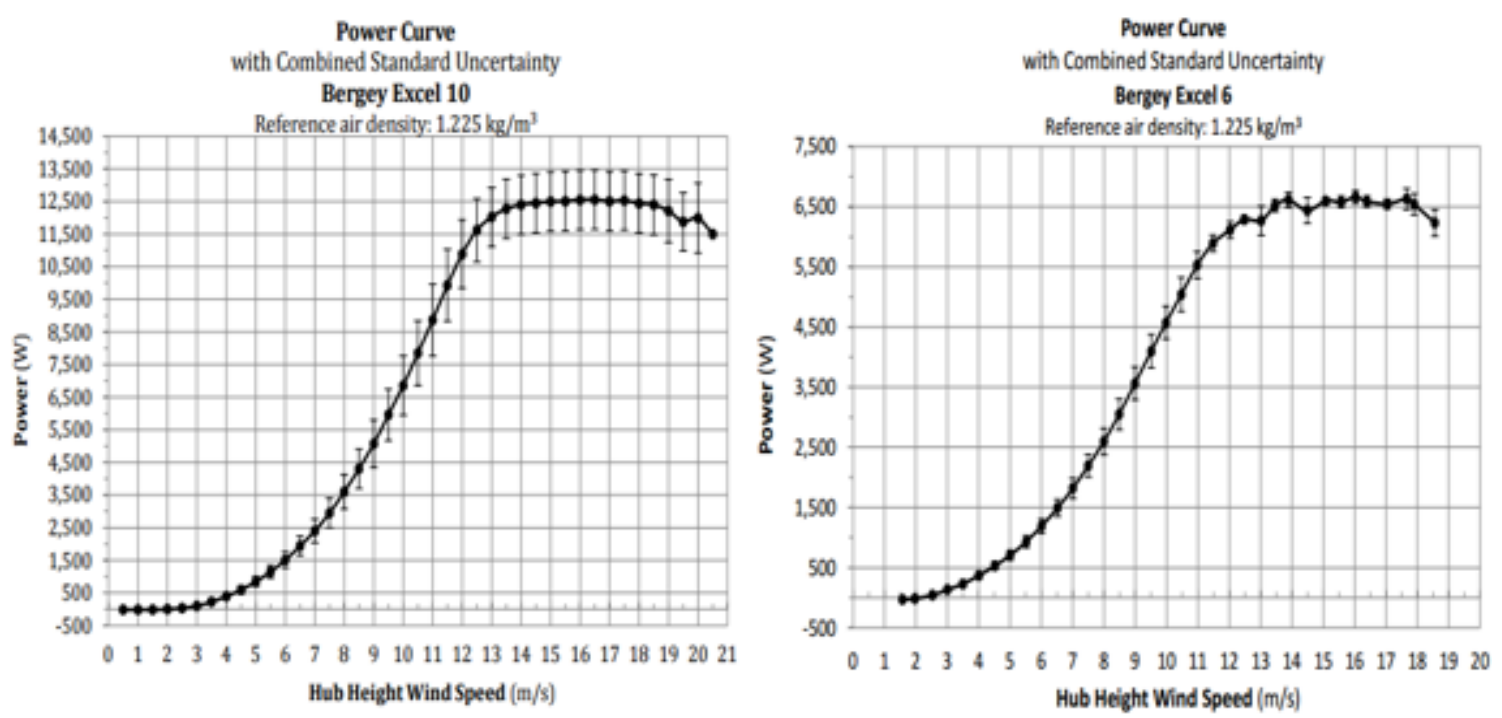

Figure 3: Bergey Excel 10 and 6 SWCC report power curves

Source: The Small Wind Certification Council (SWCC)

\subsection{Wind Turbine Power Output Calibration}

Given the data and the SWCC power curves, values for the parameters defined in equation 1 may be determined. For a given turbine, wind speed ( $V$ in equation 1$)$ is available from the chart; rotor sweep area ( $A$ in equation 1$)$ is $30.7 \mathrm{~m}^{2}$ for the $6 \mathrm{~kW}$ and $38.6 \mathrm{~m}^{2}$ for the 10 $\mathrm{kW}$. For calibration, the air density ( $\rho$ in equation 1 ) is set at a base sea level value of 1.225 $\mathrm{kg} / \mathrm{m}^{3}$. The power coefficient ( $C_{p}$ in equation 1 ) for each turbine was estimated by solving for the value at which the absolute difference from the tested power output and the predicted power output was minimized. By this measure, $C_{p}$ values of 0.285 and 0.258 were obtained for the 10 $\mathrm{kW}$ and $6 \mathrm{~kW}$ turbines, respectively.

Average air densities for the five locations are $0.91,1.08,1.13,1.15$, and $1.18 \mathrm{~kg} / \mathrm{m}^{3}$ for Boise City, Hollis, Shawnee, Miami, and Idabel, respectively. These values are entered for $\rho$ in equation 1 to obtain power output levels for the calibrated values of $C_{p}$. For wind velocity levels 
less than $V_{r}$, these less than sea level air densities result in estimated power levels of $74 \%, 88 \%$, 92\%, 94\%, and 97\% of the base level for Boise City, Hollis, Shawnee, Miami, and Idabel, respectively.

For velocity levels between $V_{r}$ and $V_{p}$ an ordinary least square regression was estimated to obtain parameter values for $\alpha_{0}, \alpha_{1}$, and $\alpha_{2}$ for each location. Estimated coefficients are reported in Table 3.

Table 3: Regression coefficients results for the power output quadratic function for the two turbine modules and five locations

\begin{tabular}{clcc}
\hline Location & \multicolumn{1}{c}{ System } & 10 kW Wind Turbine & 6 kW Wind Turbine \\
\hline Boise & Constant $\left(\alpha_{0}\right)$ & -41.78 & -12.84 \\
City & Wind Speed Linear Term $\left(\alpha_{1}\right)$ & 7.16 & 2.54 \\
& Wind Speed Quadratic Term $\left(\alpha_{2}\right)$ & -0.25 & -0.09 \\
Hollis & Constant $\left(\alpha_{0}\right)$ & -49.60 & -15.24 \\
& Wind Speed Linear Term $\left(\alpha_{1}\right)$ & 8.50 & 3.01 \\
& Wind Speed Quadratic Term $\left(\alpha_{2}\right)$ & -0.30 & -0.11 \\
\multirow{2}{*}{ Shawnee } & Constant $\left(\alpha_{0}\right)$ & & -15.92 \\
& Wind Speed Linear Term $\left(\alpha_{1}\right)$ & -51.81 & 3.14 \\
& Wind Speed Quadratic Term $\left(\alpha_{2}\right)$ & 8.88 & -0.11 \\
& & -0.31 & -16.33 \\
Miami & Constant $\left(\alpha_{0}\right)$ & & 3.22 \\
& Wind Speed Linear Term $\left(\alpha_{1}\right)$ & -53.13 & -0.12 \\
& Wind Speed Quadratic Term $\left(\alpha_{2}\right)$ & 9.11 & -16.72 \\
& & -0.32 & 3.30 \\
\hline \multirow{2}{*}{ Idabel } & Constant $\left(\alpha_{0}\right)$ & -0.33 & -0.12 \\
& Wind Speed Linear Term $\left(\alpha_{1}\right)$ & -54.39 & \\
& Wind Speed Quadratic Term $\left(\alpha_{2}\right)$ & 9.32 & \\
\hline
\end{tabular}

All parameters are significant at $99 \%$ confident level.

3.5. Assumptions for Estimating the Annual Cost of the Wind Turbines 
The wind turbine systems are assumed to be installed and used for their estimated life of 20 years. The salvage value is assumed to be zero. A 5\% interest rate and discount factor are assumed. The insurance rate is assumed to be $0.6 \%$. The assessed proportion for property tax is assumed to be 12\% [41]. Estimates of costs for both machines are reported in Table 4.

Table 4: Purchase price and annual cost for two wind turbine

\begin{tabular}{|c|c|c|c|}
\hline Description & Unit & $10 \mathrm{~kW}$ Wind Turbine & $6 \mathrm{~kW}$ Wind Turbine \\
\hline Purchase Price & $\$$ & 65,000 & 55,000 \\
\hline Life & years & \multicolumn{2}{|c|}{20} \\
\hline Depreciation & \$/year & 3,250 & 2,750 \\
\hline Interest on Average Investment & \$/year & 1,625 & 1,375 \\
\hline Insurance & \$/year & 195 & 165 \\
\hline Property Tax & \$/year & 352 & 298 \\
\hline Repairs & \$/year & 437 & 437 \\
\hline Total Annual Cost & \$/year & 5,860 & 5,025 \\
\hline
\end{tabular}

Source: Bergey Company provided purchase price and repair cost estimates for the wind turbines. Salvage value is assumed to be zero at the end of life for each of the systems.

\section{Results and Discussion}

Figures 4,5 , and 6 show the electricity consumption and power output for each wind turbine system for the five case study locations for the months of January, April, and July. Estimated electricity production is greatest in Boise City where most of the electricity consumption in winter (January) and all the consumption in spring (April) is produced by the wind turbine. Peak load summer (July) requirements exceed expected turbine output. For the other four locations, wind speeds are lower, and the power output is not sufficient to cover the electricity consumption. Average wind velocity is relatively low at Idabel, in southeast Oklahoma, and the expected electricity production from the modeled turbines is low. As the charts illustrate, location and time of year matters. 


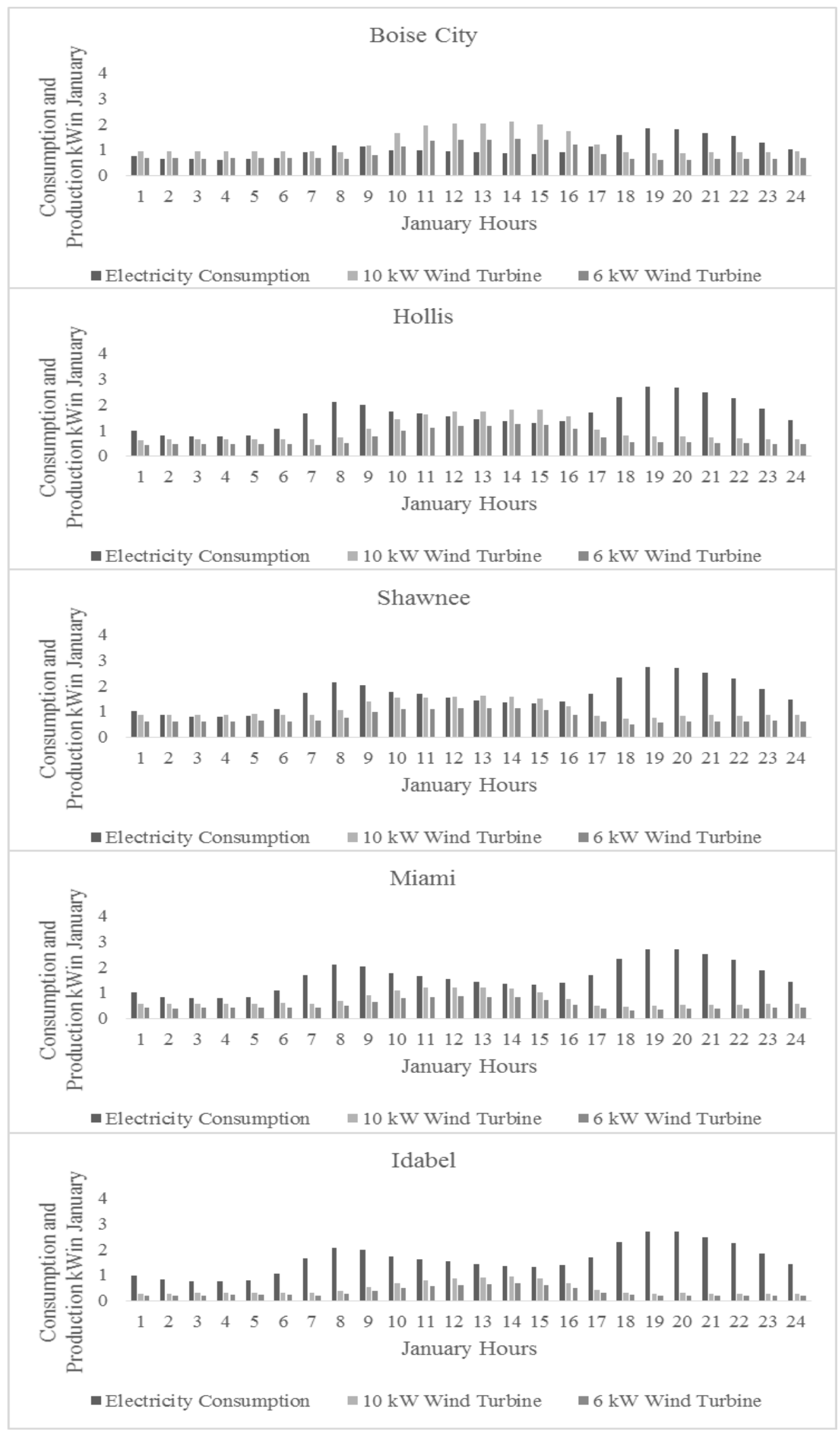

Figure 4: : Estimates of electricity consumption and power output for two wind turbine systems for the five locations, Oklahoma representative household in January. 


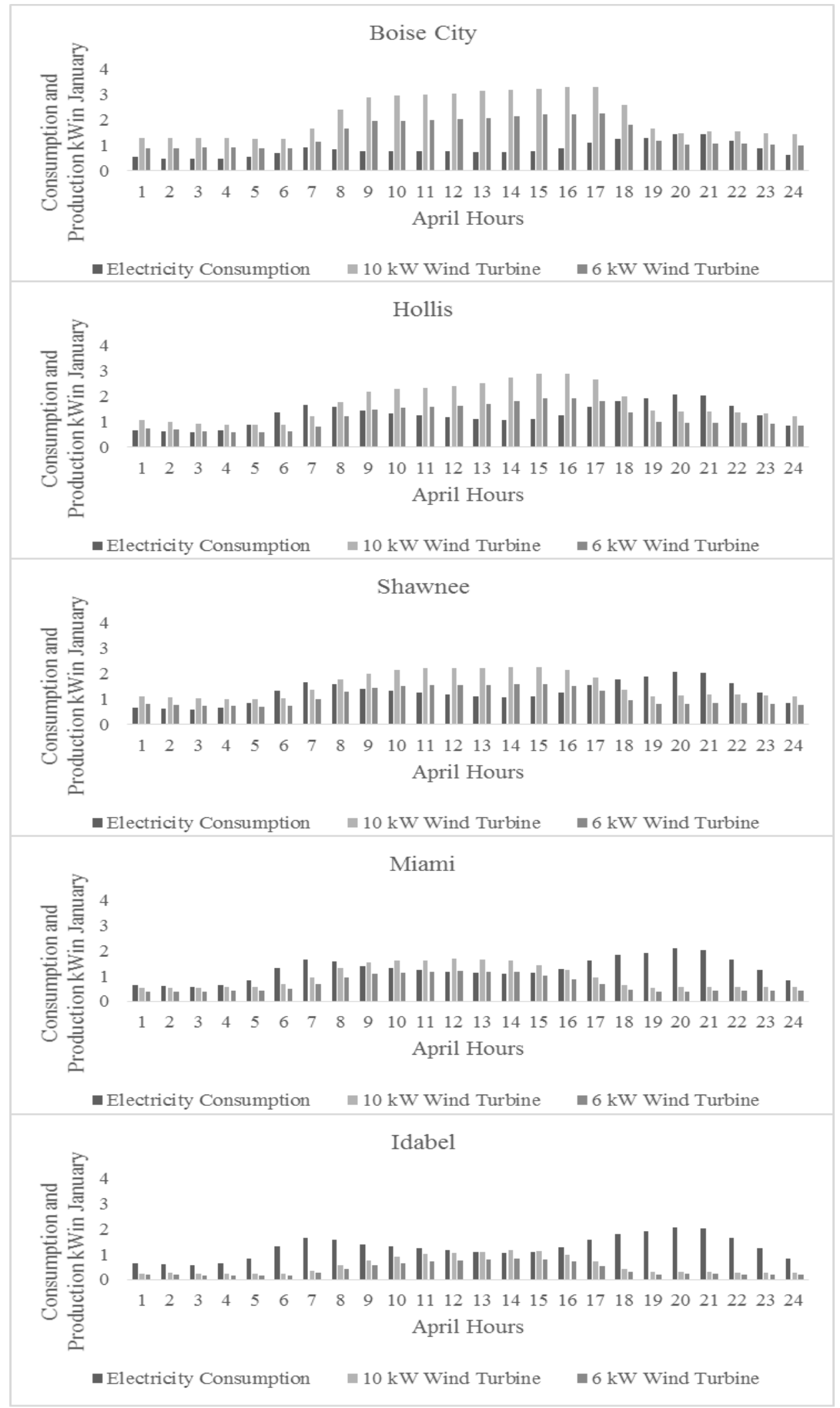

Figure 5: Estimates of electricity consumption and power output for two wind turbine systems for the five locations, Oklahoma representative household in April. 


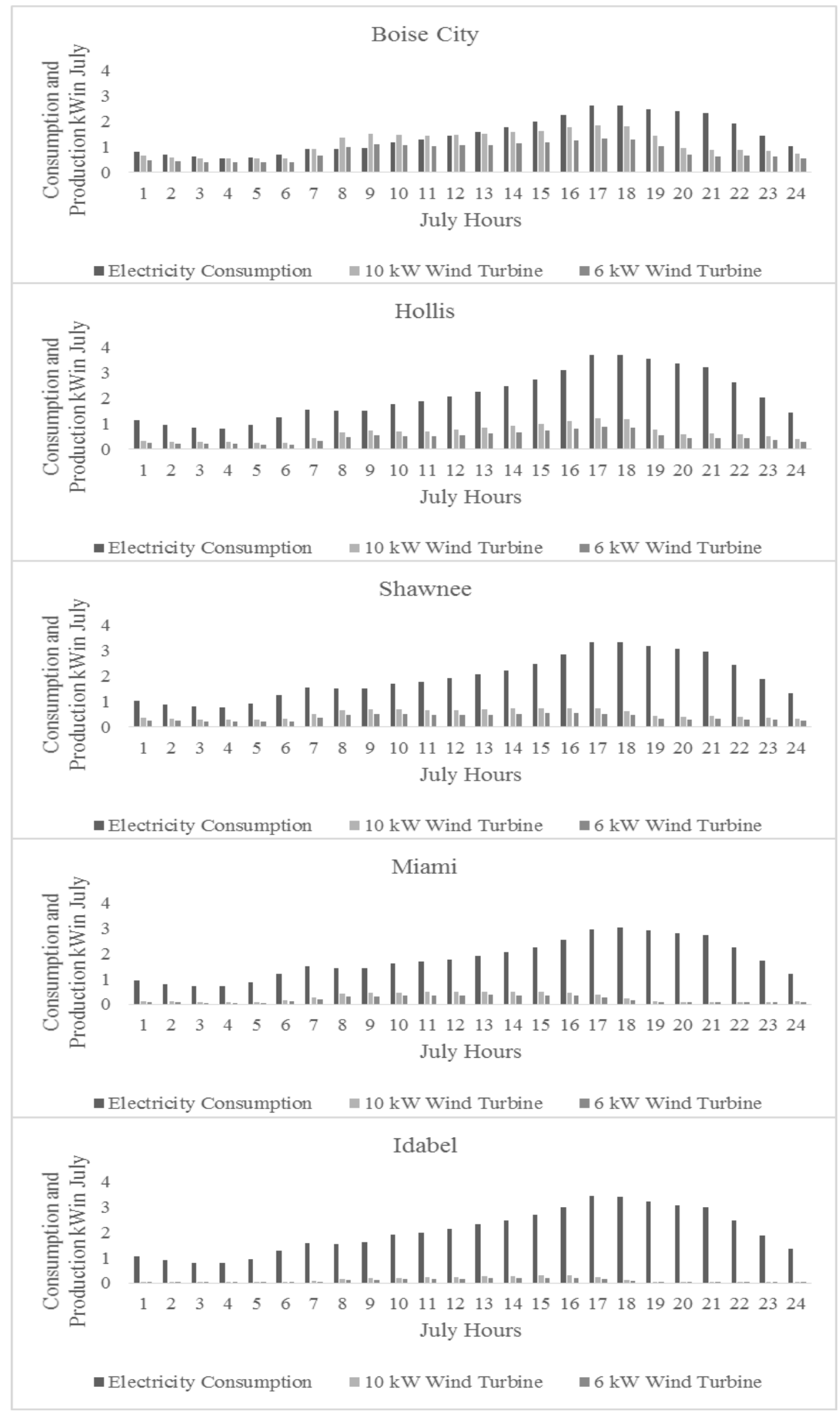

Figure 6: Estimates of electricity consumption and power output for two wind turbine systems for the five locations, Oklahoma representative household in July. 
Table 5 shows the percentage of electricity production used by the household for each location and wind turbine size. Boise City has the lowest electricity consumption and the highest power output production. Expected electricity production from $10 \mathrm{~kW}$ and $6 \mathrm{~kW}$ wind turbines located at Boise City are expected to produce $85 \%$ and $73 \%$, respectively, of annual household requirements. Whereas, turbines located at Idabel are expected to produce only $15 \%-21 \%$ of annual household requirements.

Table 5: Annual electricity consumed, produced, used, and the percentage of the representative household consumption produced by each of the two RDG systems in each location

\begin{tabular}{|c|c|c|c|c|c|c|}
\hline Location & System & $\begin{array}{c}\text { Electricity } \\
\text { Consumption } \\
(\mathrm{kWh} / \mathrm{yr})\end{array}$ & $\begin{array}{c}\text { Power } \\
\text { Production } \\
(\mathbf{k W h} / \mathbf{y r})\end{array}$ & $\begin{array}{c}\text { Power } \\
\text { Production } \\
\text { Used } \\
(\mathbf{k W h} / \mathbf{y r})\end{array}$ & $\begin{array}{c}\text { Power } \\
\text { Production } \\
\text { Used (\%) }\end{array}$ & $\begin{array}{c}\text { Percentage of } \\
\text { Household } \\
\text { Consumption } \\
\text { Produced by } \\
\text { Wind Turbine } \\
(\%) \\
\end{array}$ \\
\hline \multirow[t]{3}{*}{ Boise City } & & 9,206 & & & & \\
\hline & $10 \mathrm{~kW}$ Turbine & & 12,445 & 7,785 & $63 \%$ & $85 \%$ \\
\hline & $6 \mathrm{~kW}$ Turbine & & 8,704 & 6,709 & $77 \%$ & $73 \%$ \\
\hline \multirow[t]{3}{*}{ Hollis } & & 14,289 & & & & \\
\hline & $10 \mathrm{~kW}$ Turbine & & 9,254 & 8,125 & $88 \%$ & $57 \%$ \\
\hline & $6 \mathrm{~kW}$ Turbine & & 6,415 & 6,214 & $97 \%$ & $43 \%$ \\
\hline \multirow[t]{3}{*}{ Shawnee } & & 13,502 & & & & \\
\hline & $10 \mathrm{~kW}$ Turbine & & 8,327 & 7,522 & $90 \%$ & $56 \%$ \\
\hline & $6 \mathrm{~kW}$ Turbine & & 5,929 & 5,797 & $98 \%$ & $43 \%$ \\
\hline \multirow[t]{3}{*}{ Miami } & & 12,847 & & & & \\
\hline & $10 \mathrm{~kW}$ Turbine & & 5,087 & 4,965 & $98 \%$ & $39 \%$ \\
\hline & $6 \mathrm{~kW}$ Turbine & & 3,642 & 3,637 & $100 \%$ & $28 \%$ \\
\hline \multirow[t]{3}{*}{ Idabel } & & 13,538 & & & & \\
\hline & $10 \mathrm{~kW}$ Turbine & & 2,906 & 2,902 & $100 \%$ & $21 \%$ \\
\hline & $6 \mathrm{~kW}$ Turbine & & 2,084 & 2,084 & $100 \%$ & $15 \%$ \\
\hline
\end{tabular}


Electricity consumption and production for each block for each billing period (month) for Boise City and Idabel are shown in Appendix B and C, respectively. These locations represent the extremes in expected electricity production among the five locations. Blocks $\mathrm{F}$ and $\mathrm{J}$ for the smart meter and proposed RDG rates, respectively, are the peak load pricing blocks. A $10 \mathrm{~kW}$ machine at Boise City is expected to produce sufficient electricity to meet household requirements during the months of June and October. Production from a $6 \mathrm{~kW}$ turbine is expected to be sufficient for October. The household is not expected to be compensated for excess electricity sent to the grid during a block. For net metering systems, zero net electricity from the grid results if total production during a block exceeds total household requirement during the same block. Electricity production from either system at Idabel would be insufficient to cover household requirements during any block (Appendix C).

The annual cost for installing and maintaining each of the wind turbine systems is reported in Table 4. Payments to the utility and annual cost of electricity for the case study household for each location and each of the ten alternatives, (a) traditional meter, (b) smart meter, (c) RDG rates $6 \mathrm{~kW}$ wind turbine, (d) RDG rates $10 \mathrm{~kW}$ wind turbine, (e) traditional meter with $6 \mathrm{~kW}$ wind turbine with net metering, (f) traditional meter with $10 \mathrm{~kW}$ wind turbine with net metering, (g) smart meter with $6 \mathrm{~kW}$ wind turbine with net metering, (h) smart meter with $10 \mathrm{~kW}$ wind turbine with net metering, (i) proposed RDG rates for a $6 \mathrm{~kW}$ wind turbine grid-tied system with net metering, and (j) proposed RDG rates for a $10 \mathrm{~kW}$ wind turbine gridtied system with net metering are reported in Table 6. 
Table 6: Annual cost of electricity for a representative five locations, Oklahoma household, for three alternative rate structures

\begin{tabular}{|c|c|c|c|c|c|c|c|c|c|c|c|c|}
\hline \multirow[t]{2}{*}{ Location } & \multirow[t]{2}{*}{ System } & \multirow[t]{2}{*}{ Unit } & \multicolumn{3}{|c|}{$\begin{array}{c}\text { Alternative I: Traditional } \\
\text { Meter }\end{array}$} & \multicolumn{3}{|c|}{ Alternative II: Smart Meter } & \multicolumn{4}{|c|}{ Proposed Alternative III: Smart plus RDG } \\
\hline & & & $\begin{array}{l}\text { Payment } \\
\text { to Utility }\end{array}$ & $\begin{array}{l}\text { Payment } \\
\text { to Utility } \\
\text { with Net } \\
\text { Metering }\end{array}$ & $\begin{array}{l}\text { Total } \\
\text { Cost }\end{array}$ & $\begin{array}{l}\text { Payment } \\
\text { to Utility }\end{array}$ & $\begin{array}{l}\text { Payment } \\
\text { to Utility } \\
\text { with Net } \\
\text { Metering }\end{array}$ & $\begin{array}{l}\text { Total } \\
\text { Cost }\end{array}$ & $\begin{array}{c}\text { Payment } \\
\text { to Utility } \\
\text { without } \\
\text { Net } \\
\text { Metering }\end{array}$ & $\begin{array}{l}\text { Payment } \\
\text { to Utility } \\
\text { with Net } \\
\text { Metering }\end{array}$ & $\begin{array}{c}\text { Total } \\
\text { Cost } \\
\text { without } \\
\text { Net } \\
\text { Metering }\end{array}$ & $\begin{array}{c}\text { Total } \\
\text { Cost } \\
\text { with Net } \\
\text { Metering }\end{array}$ \\
\hline \multirow[t]{3}{*}{ Boise City } & Grid-Only & $\$ / y r$ & 870 & & & 894 & & & & & & \\
\hline & $\begin{array}{l}10 \mathrm{~kW} \\
\text { Wind } \\
\text { Turbine }\end{array}$ & $\$ / y r$ & & 198 & 6,058 & & 213 & 6,073 & 309 & 286 & 6,169 & 6,146 \\
\hline & $\begin{array}{l}6 \mathrm{~kW} \text { Wind } \\
\text { Turbine }\end{array}$ & $\$ / y r$ & & 274 & 5,299 & & 289 & 5,314 & 374 & 364 & 5,399 & 5,389 \\
\hline \multirow[t]{3}{*}{ Hollis } & Grid-Only & $\$ / y r$ & 1,191 & & & 1,199 & & & & & & \\
\hline & $\begin{array}{l}10 \mathrm{~kW} \\
\text { Wind } \\
\text { Turbine }\end{array}$ & $\$ / y r$ & & 597 & 6,457 & & 617 & 6,477 & 654 & 629 & 6,514 & 6,489 \\
\hline & $\begin{array}{l}6 \mathrm{~kW} \text { Wind } \\
\text { Turbine }\end{array}$ & $\$ / y r$ & & 784 & 5,809 & & 807 & 5,832 & 764 & 757 & 5,789 & 5,782 \\
\hline \multirow[t]{3}{*}{ Shawnee } & Grid-Only & $\$ / y r$ & 1,122 & & & 1,137 & & & & & & \\
\hline & $\begin{array}{l}10 \mathrm{~kW} \\
\text { Wind } \\
\text { Turbine }\end{array}$ & $\$ / y r$ & & 592 & 6,452 & & 626 & 6,486 & 658 & 633 & 6,518 & 6,493 \\
\hline & $\begin{array}{l}6 \mathrm{~kW} \text { Wind } \\
\text { Turbine }\end{array}$ & $\$ / y r$ & & 763 & 5,788 & & 893 & 5,918 & 749 & 738 & 5,774 & 5,763 \\
\hline \multirow[t]{3}{*}{ Miami } & Grid-Only & $\$ / y r$ & 1,066 & & & 1,072 & & & & & & \\
\hline & $\begin{array}{l}10 \mathrm{~kW} \\
\text { Wind } \\
\text { Turbine }\end{array}$ & $\$ / y r$ & & 773 & 6,633 & & 796 & 6,656 & 725 & 721 & 6,585 & 6,581 \\
\hline & $\begin{array}{l}6 \mathrm{~kW} \text { Wind } \\
\text { Turbine }\end{array}$ & $\$ / y r$ & & 871 & 5,896 & & 622 & 5,647 & 789 & 789 & 5,814 & 5,814 \\
\hline \multirow[t]{3}{*}{ Idabel } & Grid-Only & $\$ / \mathrm{yr}$ & 1,128 & & & 1,145 & & & & & & \\
\hline & $\begin{array}{l}10 \mathrm{~kW} \\
\text { Wind } \\
\text { Turbine }\end{array}$ & $\$ / y r$ & & 981 & 6,841 & & 1,005 & 6,865 & 900 & 900 & 6,760 & 6,760 \\
\hline & $\begin{array}{l}6 \mathrm{~kW} \text { Wind } \\
\text { Turbine }\end{array}$ & $\$ / \mathrm{yr}$ & & 1,026 & 6,051 & & 1,048 & 6,073 & 939 & 939 & 5,964 & 5,964 \\
\hline
\end{tabular}


The annual cost range among the five locations is estimated to be $\$ 894-\$ 1,199$ for the smart meter system and $\$ 870-\$ 1,191$ for the traditional meter system. The pricing structure provides a small incentive for the modeled household to select the traditional meter rate structure. These findings are based on the assumption that switching from the traditional to smart meter rate structure does not alter household behavior. If the household adjusted time of electricity use to reduce consumption during the June through October (block F) weekday afternoon (2 p.m. to 7 p.m.) high rate time period, savings to the household from adopting the smart meter rate structure would be greater than those estimated. Presumably, the utility could also benefit from the reduction in use during the high cost peak load time period.

The results as reported in Table 6 also show that none of the two household wind turbine systems are economically competitive with grid provided electricity. The estimated annual cost of $\$ 5,389$ for the least costly $6 \mathrm{~kW}$ wind turbine system, is more than five times greater than the annual cost of purchasing from the grid via a smart meter system in Boise City. Given the budgeted price structure, and the wind resources, household wind turbines are not economically viable alternatives for the region. The proposed RDG rates relative to the traditional and smart meter rates would increase the cost of electricity for Boise City, Hollis, and Shawnee households that install a $10 \mathrm{~kW}$ turbine.

Table 7 shows the breakeven installation costs for the two selected wind turbine systems for each location. These breakeven prices can be compared to the estimated installation costs of $\$ 65,000$ for the $10 \mathrm{~kW}$ system and $\$ 55,000$ for the $6 \mathrm{~kW}$ system. Among the 20 situations evaluated, the highest breakeven installation cost of $\$ 3,275$ is for the $10 \mathrm{~kW}$ wind turbine located at Boise City for a household on a smart meter rate system. In other words, to break even with grid-only electricity the installed cost of the system would have to decrease by $\$ 61,725$. 
Breakeven values less than zero as reported for the $6 \mathrm{~kW}$ systems for Miami and Idabel imply that households at these locations would have to be paid to install this wind turbine system.

Table 7: Breakeven prices of the two wind turbines for the for the Oklahoma five locations (\$)

\begin{tabular}{llcc}
\hline Location & \multicolumn{1}{c}{ System } & $\begin{array}{c}\text { Household using } \\
\text { Alternative I: } \\
\text { Traditional Meter }\end{array}$ & $\begin{array}{c}\text { Household using } \\
\text { Alternative II: Smart } \\
\text { Meter }\end{array}$ \\
\hline Boise & 10 kW Turbine & $3,018 \dagger$ & 3,275 \\
City & $6 \mathrm{~kW}$ Turbine & $2,043 \dagger$ & 2,301 \\
Hollis & 10 kW Turbine & 2,747 & 2,837 \\
& $6 \mathrm{~kW}$ Turbine & 1,155 & 1,245 \\
Shawnee & $10 \mathrm{~kW}$ Turbine & 1,834 & 2,028 \\
& $6 \mathrm{~kW}$ Turbine & 518 & 711 \\
Miami & $10 \mathrm{~kW}$ Turbine & 43 & 116 \\
& $6 \mathrm{~kW}$ Turbine & $<0$ & $<0$ \\
Idabel & $10 \mathrm{~kW}$ Turbine & $<0$ & $<0$ \\
& $6 \mathrm{~kW}$ Turbine & $<0$ & $<0$ \\
\hline
\end{tabular}

$\uparrow$ These breakeven prices can be compared to the estimated installation costs of $\$ 65,000$ for the $10 \mathrm{~kW}$ system and $\$ 55,000$ for the $6 \mathrm{~kW}$ system.

\section{Conclusion}

The study was conducted to determine the annual cost of electricity for representative households at five case study locations and to determine the economics of grid-tied wind turbines. Annual electricity consumption for the representative households ranged from 9,206 $\mathrm{kWh}$ to $14,289 \mathrm{kWh}$. Annual electricity production for the $\$ 55,0006 \mathrm{~kW}$ system ranged from 2,084 $\mathrm{kWh}$ at Idabel to $8,704 \mathrm{kWh}$ at Boise City. The $6 \mathrm{~kW}$ system produced $73 \%$ of household requirements at Boise City but only $15 \%$ at Idabel. Production for the $\$ 65,00010 \mathrm{~kW}$ system ranged from 2,906 kWh at Idabel to 12,445 kWh at Boise City. Among locations, the $6 \mathrm{~kW}$ 
system is expected to produce $70 \%$ as much electricity as the $10 \mathrm{~kW}$ system. The $10 \mathrm{~kW}$ system produced $85 \%$ of household requirements at Boise City but only $21 \%$ at Idabel. Wind resources vary greatly across the modeled locations.

For the modeled households among the five locations, annual electricity cost was estimated to be $\$ 894-1,199$ for the smart meter system and $\$ 870-1,191$ for the traditional meter system. The estimated annual cost of $\$ 5,389$ for the least costly household grid tied production system, a $6 \mathrm{~kW}$ wind system, is five times greater than the annual cost of purchasing from the

grid via a smart meter system. If external consequences of electricity generation and distribution are ignored, given current and proposed rate structures and prices, the grid-tied wind systems are not economically competitive for households in the region.

Grid-only electricity under the traditional meter rates is the least-cost alternative for each of the five locations. Consequently, for a given and fixed household consumption pattern, the utility would collect more under the smart meter rates. Of course, household consumption patterns may change under the incentives provided by the smart meter rates relative to the traditional accumulation meter rates.

\section{Acknowledgments}

Funding was provided by the Jean \& Patsy Neustadt Chair, by the USDA National Institute of Food and Agriculture, Hatch grant number H-2824, and by the Oklahoma Agricultural Experiment Station. 


\begin{tabular}{|c|c|c|c|}
\hline \multirow{2}{*}{$\begin{array}{l}\text { Time and quantity of } \\
\text { electricity used }\end{array}$} & \multirow{2}{*}{ Block } & Price & \multirow{2}{*}{$\begin{array}{c}\text { Fuel Cost } \\
\text { Adjustment } \dagger \\
(\notin \text { per } k W h)\end{array}$} \\
\hline & & $\begin{array}{l}\text { (c per } \\
\text { kWh })\end{array}$ & \\
\hline Base Charge & \multicolumn{2}{|c|}{$\begin{array}{c}\text { Alternative I: Traditional Meter } \\
13.00\end{array}$} & \\
\hline June through September & & & 2.38 \\
\hline $0 \leq \mathrm{kWh}$ per month $\leq 1,400$ & $\mathbf{A}$ & 5.73 & \\
\hline $\mathrm{kWh}$ per month $>1,400$ & B & 6.68 & \\
\hline November through April & & & 2.22 \\
\hline $0 \leq \mathrm{kWh}$ per month $\leq 600$ & $\mathbf{C}$ & 5.73 & \\
\hline $\mathrm{kWh}$ per month $>600$ & D & 1.37 & \\
\hline May and October & $\mathbf{E}$ & 5.73 & \\
\hline
\end{tabular}

Base Charge

Alternative II: Smart Meter

June through October

2 p.m. through 7 p.m. weekdays

7:01 p.m. through 1:59 p.m., and

weekends

13.00

November through May

First $600 \mathrm{kWh}$ per month

Additional kWh

$\begin{array}{rr}\text { F } & 14.00 \\ \mathbf{G} & 2.70 \\ & \\ \mathbf{H} & 5.73 \\ \mathbf{I} & 1.37\end{array}$

Proposed Alternative III: Smart plus RDG

Base Charge

18.00

Maximum 15-minute Period

$+$

Monthly Charge

June through October

\begin{tabular}{lrrr} 
2 p.m. through 7 p.m. weekdays & $\mathbf{J}$ & 17.30 & 4.26 \\
7:01 p.m. through 1:59 p.m., and & $\mathbf{K}$ & 1.37 & 2.11 \\
weekends & $\mathbf{L}$ & 1.37 & 2.22 \\
\hline
\end{tabular}

Source: Oklahoma Corporation Commission

$\dagger$ Fuel adjustment charge is a surcharge added to compensate for increases, usually unanticipated, in the price of energy (coal and natural gas).

\$ The "maximum demand" charge is determined by multiplying use $(\mathrm{kWh})$ during the 15 -minute period during the month for which withdrawal from the grid was greatest by \$2.68 (Oklahoma Gas \& Electric, 2012;

Champion, 2016). Thus, this charge varies with each month and each system. For the representative household it ranged from $\$ 1.38$ for the month of April to \$2.24 for the month of August. Since 15-minute period data were not available, withdrawal from the grid for the hour of the month with the greatest withdrawal was divided by four. 
Appendix B. Electricity Consumption and Production for each Block in Boise City

\begin{tabular}{|c|c|c|c|c|c|c|c|c|}
\hline \multirow[t]{2}{*}{ Month } & \multirow[t]{2}{*}{ Block } & \multirow[b]{2}{*}{ kWh/block/year } & \multicolumn{3}{|c|}{$6 \mathrm{~kW}$} & \multicolumn{3}{|c|}{$10 \mathrm{~kW}$} \\
\hline & & & Production & $\begin{array}{c}\text { Net Used } \\
\text { from Grid } \\
\mathrm{kWh} / \mathrm{block} / \mathrm{year}\end{array}$ & $\begin{array}{c}\text { Excess Sent } \\
\text { to Grid }\end{array}$ & Production & $\begin{array}{c}\text { Net Used } \\
\text { from Grid } \\
\mathrm{kWh} / \mathrm{block} / \text { year }\end{array}$ & $\begin{array}{c}\text { Excess Sent } \\
\text { to Grid }\end{array}$ \\
\hline \multirow{3}{*}{ June } & & & & Traditional Me & & & & \\
\hline & A & 888 & 818 & 69 & 0 & 1158 & 0 & 271 \\
\hline & B & 0 & 0 & 0 & 0 & 0 & 0 & 0 \\
\hline \multirow[t]{2}{*}{ July } & A & 1080 & 607 & 472 & 0 & 848 & 232 & 0 \\
\hline & $\mathrm{B}$ & 0 & 0 & 0 & 0 & 0 & 0 & 0 \\
\hline \multirow[t]{2}{*}{ August } & A & 983 & 496 & 487 & 0 & 691 & 291 & 0 \\
\hline & $\mathrm{B}$ & 0 & 0 & 0 & 0 & 0 & 0 & 0 \\
\hline \multirow[t]{2}{*}{ September } & A & 799 & 599 & 199 & 0 & 842 & 0 & 44 \\
\hline & $\mathrm{B}$ & 0 & 0 & 0 & 0 & 0 & 0 & 0 \\
\hline \multirow[t]{2}{*}{ November } & $\mathrm{C}$ & 600 & 600 & 0 & 0 & 600 & 0 & 0 \\
\hline & $\mathrm{D}$ & 71 & 80 & 0 & 9 & 373 & 0 & 302 \\
\hline \multirow[t]{2}{*}{ December } & $\mathrm{C}$ & 600 & 600 & 0 & 0 & 600 & 0 & 0 \\
\hline & $\mathrm{D}$ & 168 & 75 & 93 & 0 & 370 & 0 & 202 \\
\hline January & $\mathrm{C}$ & 600 & 600 & 0 & 0 & 600 & 0 & 0 \\
\hline & $\mathrm{D}$ & 181 & 38 & 143 & 0 & 314 & 0 & 132 \\
\hline February & $\mathrm{C}$ & 600 & 600 & 0 & 0 & 600 & 0 & 0 \\
\hline & $\mathrm{D}$ & 82 & 91 & 0 & 9 & 398 & 0 & 317 \\
\hline March & $\mathrm{C}$ & 600 & 600 & 0 & 0 & 600 & 0 & 0 \\
\hline & $\mathrm{D}$ & 78 & 273 & 0 & 195 & 663 & 0 & 585 \\
\hline April & $\mathrm{C}$ & 600 & 600 & 0 & 0 & 600 & 0 & 0 \\
\hline & $\mathrm{D}$ & 6 & 453 & 0 & 446 & 941 & 0 & 935 \\
\hline May & $\mathrm{E}$ & 604 & 878 & 0 & 274 & 1252 & 0 & 647 \\
\hline October & $\mathrm{E}$ & 667 & 697 & 0 & 30 & 994 & 0 & 327 \\
\hline & & & & Smart Meter & & & & \\
\hline June & $\mathrm{F}$ & 247 & 212 & 35 & 0 & 303 & 0 & 56 \\
\hline & $\mathrm{G}$ & 640 & 606 & 34 & 0 & 855 & 0 & 215 \\
\hline July & $\mathrm{F}$ & 316 & 165 & 150 & 0 & 231 & 85 & 0 \\
\hline & G & 764 & 442 & 322 & 0 & 617 & 147 & 0 \\
\hline August & $\mathrm{F}$ & 284 & 126 & 158 & 0 & 175 & 108 & 0 \\
\hline & G & 699 & 370 & 329 & 0 & 516 & 183 & 0 \\
\hline September & $\mathrm{F}$ & 227 & 137 & 90 & 0 & 192 & 34 & 0 \\
\hline & $\mathrm{G}$ & 572 & 462 & 109 & 0 & 650 & 0 & 78 \\
\hline October & $\mathrm{F}$ & 164 & 150 & 14 & 0 & 216 & 0 & 51 \\
\hline & $\mathrm{G}$ & 503 & 547 & 0 & 44 & 778 & 0 & 275 \\
\hline November & $\mathrm{H}$ & 600 & 600 & 0 & 0 & 600 & 0 & 0 \\
\hline & I & 71 & 80 & 0 & 9 & 373 & 0 & 302 \\
\hline December & $\mathrm{H}$ & 600 & 600 & 0 & 0 & 600 & 0 & 0 \\
\hline & I & 168 & 75 & 93 & 0 & 370 & 0 & 202 \\
\hline January & $\mathrm{H}$ & 600 & 600 & 0 & 0 & 600 & 0 & 0 \\
\hline & I & 181 & 38 & 143 & 0 & 314 & 0 & 132 \\
\hline February & $\mathrm{H}$ & 600 & 600 & 0 & 0 & 600 & 0 & 0 \\
\hline & I & 82 & 91 & 0 & 9 & 398 & 0 & 317 \\
\hline March & $\mathrm{H}$ & 600 & 600 & 0 & 0 & 600 & 0 & 0 \\
\hline & I & 78 & 273 & 0 & 195 & 663 & 0 & 585 \\
\hline April & $\mathrm{H}$ & 600 & 600 & 0 & 0 & 600 & 0 & 0 \\
\hline & I & 6 & 453 & 0 & 446 & 941 & 0 & 935 \\
\hline May & $\mathrm{H}$ & 600 & 600 & 0 & 0 & 600 & 0 & 0 \\
\hline & I & 4 & 278 & 0 & 274 & 652 & 0 & 647 \\
\hline & & & & Proposed RD & & & & \\
\hline June & $\mathrm{J}$ & 247 & 212 & 35 & 0 & 303 & 0 & 56 \\
\hline & $\mathrm{K}$ & 640 & 606 & 34 & 0 & 855 & 0 & 215 \\
\hline July & $\mathrm{J}$ & 316 & 165 & 150 & 0 & 231 & 85 & 0 \\
\hline & $\mathrm{K}$ & 764 & 442 & 322 & 0 & 617 & 147 & 0 \\
\hline August & $\mathrm{J}$ & 284 & 126 & 158 & 0 & 175 & 108 & 0 \\
\hline & $\mathrm{K}$ & 699 & 370 & 329 & 0 & 516 & 183 & 0 \\
\hline September & $\mathrm{J}$ & 227 & 137 & 90 & 0 & 192 & 34 & 0 \\
\hline & $\mathrm{K}$ & 572 & 462 & 109 & 0 & 650 & 0 & 78 \\
\hline October & $\mathrm{J}$ & 164 & 150 & 14 & 0 & 216 & 0 & 51 \\
\hline & $\mathrm{K}$ & 503 & 547 & 0 & 44 & 778 & 0 & 275 \\
\hline November & $\mathrm{L}$ & 671 & 680 & 0 & 9 & 973 & 0 & 302 \\
\hline December & $\mathrm{L}$ & 768 & 675 & 93 & 0 & 970 & 0 & 202 \\
\hline January & $\mathrm{L}$ & 781 & 638 & 143 & 0 & 914 & 0 & 132 \\
\hline February & $\mathrm{L}$ & 682 & 691 & 0 & 9 & 998 & 0 & 317 \\
\hline March & $\mathrm{L}$ & 678 & 873 & 0 & 195 & 1263 & 0 & 585 \\
\hline April & $\mathrm{L}$ & 606 & 1053 & 0 & 446 & 1541 & 0 & 935 \\
\hline May & $\mathrm{L}$ & 604 & 878 & 0 & 274 & 1252 & 0 & 647 \\
\hline
\end{tabular}




\begin{tabular}{|c|c|c|c|c|c|c|c|c|}
\hline \multirow[t]{3}{*}{ Month } & \multirow[t]{3}{*}{ Block } & \multirow{3}{*}{$\begin{array}{c}\text { Total Use } \\
\text { kWh/block/year }\end{array}$} & \multicolumn{3}{|c|}{$6 \mathrm{~kW}$} & \multicolumn{3}{|c|}{$10 \mathrm{~kW}$} \\
\hline & & & Production & $\begin{array}{l}\text { Net Used } \\
\text { from } \\
\text { Grid }\end{array}$ & $\begin{array}{l}\text { Excess Sent } \\
\text { to Grid }\end{array}$ & Production & $\begin{array}{c}\text { Net Used from } \\
\text { Grid }\end{array}$ & $\begin{array}{c}\text { Excess Sent } \\
\text { to Grid }\end{array}$ \\
\hline & & & \multicolumn{3}{|c|}{ kWh/block/year } & \multicolumn{3}{|c|}{ kWh/block/year } \\
\hline & & & & Tradition: & Meter & & & \\
\hline \multirow[t]{2}{*}{ June } & A & 1284 & 116 & 1168 & 0 & 161 & 1122 & 0 \\
\hline & B & 0 & 0 & 0 & 0 & 0 & 0 & 0 \\
\hline \multirow[t]{2}{*}{ July } & A & 1400 & 67 & 1333 & 0 & 93 & 1307 & 0 \\
\hline & B & 113 & 0 & 113 & 0 & 0 & 113 & 0 \\
\hline \multirow[t]{2}{*}{ August } & A & 1314 & 61 & 1252 & 0 & 85 & 1228 & 0 \\
\hline & B & 0 & 0 & 0 & 0 & 0 & 0 & 0 \\
\hline September & A & 1239 & 86 & 1153 & 0 & 120 & 1119 & 0 \\
\hline & B & 0 & 0 & 0 & 0 & 0 & 0 & 0 \\
\hline November & $\mathrm{C}$ & 600 & 179 & 421 & 0 & 249 & 351 & 0 \\
\hline & D & 370 & 0 & 370 & 0 & 0 & 370 & 0 \\
\hline December & $\mathrm{C}$ & 600 & 218 & 382 & 0 & 304 & 296 & 0 \\
\hline & D & 507 & 0 & 507 & 0 & 0 & 507 & 0 \\
\hline January & $\mathrm{C}$ & 600 & 241 & 359 & 0 & 336 & 264 & 0 \\
\hline & D & 589 & 0 & 589 & 0 & 0 & 589 & 0 \\
\hline February & $\mathrm{C}$ & 600 & 236 & 364 & 0 & 329 & 271 & 0 \\
\hline & D & 429 & 0 & 429 & 0 & 0 & 429 & 0 \\
\hline March & $\mathrm{C}$ & 600 & 310 & 290 & 0 & 433 & 167 & 0 \\
\hline & $\mathrm{D}$ & 431 & 0 & 431 & 0 & 0 & 431 & 0 \\
\hline April & $\mathrm{C}$ & 600 & 287 & 313 & 0 & 401 & 199 & 0 \\
\hline & D & 318 & 0 & 318 & 0 & 0 & 318 & 0 \\
\hline May & E & 936 & 167 & 769 & 0 & 232 & 704 & 0 \\
\hline October & $\mathrm{E}$ & 1008 & 116 & 892 & 0 & 161 & 847 & 0 \\
\hline & & & & Smart I & & & & \\
\hline June & $\mathrm{F}$ & 349 & 33 & 317 & 0 & 45 & 304 & 0 \\
\hline & G & 934 & 83 & 851 & 0 & 116 & 818 & 0 \\
\hline July & $\mathrm{F}$ & 419 & 21 & 398 & 0 & 29 & 390 & 0 \\
\hline & G & 1094 & 46 & 1048 & 0 & 63 & 1031 & 0 \\
\hline August & $\mathrm{F}$ & 366 & 20 & 346 & 0 & 28 & 338 & 0 \\
\hline & G & 948 & 41 & 907 & 0 & 57 & 891 & 0 \\
\hline September & $\mathrm{F}$ & 337 & 21 & 316 & 0 & 29 & 308 & 0 \\
\hline & G & 901 & 65 & 836 & 0 & 90 & 811 & 0 \\
\hline October & $\mathrm{F}$ & 237 & 28 & 209 & 0 & 39 & 198 & 0 \\
\hline & G & 772 & 88 & 684 & 0 & 122 & 649 & 0 \\
\hline November & $\mathrm{H}$ & 600 & 179 & 421 & 0 & 249 & 351 & 0 \\
\hline & I & 370 & 0 & 370 & 0 & 0 & 370 & 0 \\
\hline December & $\mathrm{H}$ & 600 & 218 & 382 & 0 & 304 & 296 & 0 \\
\hline & I & 507 & 0 & 507 & 0 & 0 & 507 & 0 \\
\hline January & $\mathrm{H}$ & 600 & 241 & 359 & 0 & 336 & 264 & 0 \\
\hline & I & 589 & 0 & 589 & 0 & 0 & 589 & 0 \\
\hline February & $\mathrm{H}$ & 600 & 236 & 364 & 0 & 329 & 271 & 0 \\
\hline & I & 429 & 0 & 429 & 0 & 0 & 429 & 0 \\
\hline March & $\mathrm{H}$ & 600 & 310 & 290 & 0 & 433 & 167 & 0 \\
\hline & I & 431 & 0 & 431 & 0 & 0 & 431 & 0 \\
\hline April & $\mathrm{H}$ & 600 & 287 & 313 & 0 & 401 & 199 & 0 \\
\hline & I & 318 & 0 & 318 & 0 & 0 & 318 & 0 \\
\hline May & $\mathrm{H}$ & 600 & 167 & 433 & 0 & 232 & 368 & 0 \\
\hline & I & 336 & 0 & 336 & 0 & 0 & 336 & 0 \\
\hline & & & & Propose & DG & & & \\
\hline June & $\mathrm{J}$ & 349 & 33 & 317 & 0 & 45 & 304 & 0 \\
\hline & $\mathrm{K}$ & 934 & 83 & 851 & 0 & 116 & 818 & 0 \\
\hline July & $\mathrm{J}$ & 419 & 21 & 398 & 0 & 29 & 390 & 0 \\
\hline & $\mathrm{K}$ & 1094 & 46 & 1048 & 0 & 63 & 1031 & 0 \\
\hline August & $\mathrm{J}$ & 366 & 20 & 346 & 0 & 28 & 338 & 0 \\
\hline & K & 948 & 41 & 907 & 0 & 57 & 891 & 0 \\
\hline September & J & 337 & 21 & 316 & 0 & 29 & 308 & 0 \\
\hline & $\mathrm{K}$ & 901 & 65 & 836 & 0 & 90 & 811 & 0 \\
\hline October & $\mathrm{J}$ & 237 & 28 & 209 & 0 & 39 & 198 & 0 \\
\hline & $\mathrm{K}$ & 772 & 88 & 684 & 0 & 122 & 649 & 0 \\
\hline November & $\mathrm{L}$ & 970 & 179 & 791 & 0 & 249 & 721 & 0 \\
\hline December & $\mathrm{L}$ & 1107 & 218 & 889 & 0 & 304 & 803 & 0 \\
\hline January & $\mathrm{L}$ & 1189 & 241 & 948 & 0 & 336 & 853 & 0 \\
\hline February & $\mathrm{L}$ & 1029 & 236 & 793 & 0 & 329 & 700 & 0 \\
\hline March & $\mathrm{L}$ & 1031 & 310 & 721 & 0 & 433 & 598 & 0 \\
\hline April & $\mathrm{L}$ & 918 & 287 & 631 & 0 & 401 & 518 & 0 \\
\hline May & L & 936 & 167 & 769 & 0 & 232 & 704 & 0 \\
\hline
\end{tabular}




\section{References}

[1] Oklahoma Mesonet. Mesonet Sites. Internet site: https://www.mesonet.org/index.php/site/sites/station_names_map\# (Accessed February, 23, 2016).

[2] U.S. Department of Energy, Energy Efficiency \& Renewable Energy. Utility-Scale Land Based 80-Meter Wind Maps. Internet site: http://apps2.eere.energy.gov/wind/windexchange/wind_maps.asp (Accessed February, 23, 2016).

[3] Rodgers, Richard, Oscar Hammerstein, and Lynn Riggs. Oklahoma! a musical play. Williamson Music, 1943.

[4] Shannon Ferrell and Joshua Conaway. Wind Energy Industry Impacts in Oklahoma, State Chamber of Oklahoma Research Foundation. 2015. Internet Site: http://www.okstatechamber.com/sites/www.okstatechamber.com/files/RevisedReport_Win dStudy9_3_15.pdf (Accessed February 18, 2016)

[5] Oklahoma Department of Commerce. Tax Credits. Internet site: http://okcommerce.gov/stateenergy-office/tax-credits/ (Accessed March 3, 2016).

[6] Vilsack, Tom and C.Z.F. Clark. On-Farm Renewable Energy Production Survey (2009). Vol. 3. Special Studies. National Agricultural Statistics Service (NASS) and United States Department of Agriculture (USDA). Part 6. AC-07-SS-6. Issued February 2011.

[7] National Agricultural Statistics Service (NASS) and Oklahoma Department of Agriculture, Food and Forestry (ODAF). Oklahoma Agricultural Statistics. 2015. Internet site: http://www.nass.usda.gov/Statistics_by_State/Oklahoma/Publications/Annual_Statistical_ Bulletin/ok_bulletin_2015.pdf (Accessed December, 5, 2015)

[8] Oklahoma Legislature, Constitution of the State of Oklahoma, Article IX section 18, Corporations.

[9] Oklahoma Corporation Commission (OCC), Chapter35: Electric Utility Rules, Vol. 31 Number 24, 2014. Internet site: http://www.occeweb.com/rules/Ch\%2035\%20Electric\%20Rules\%20eff\%209-122014\%20Searchable.pdf (Accessed November, 20, 2015)

[10] Blumsack, Seth and Alisha Fernandez. "Ready or not, here comes the smart grid." Energy 37.1 (2012): 61-68.

[11] Oklahoma Corporation Commission (OCC). Electricity Prices for Oklahoma Gas and Electric Company, 2015.

[12] Joskow, Paul L., and Catherine D. Wolfram. "Dynamic pricing of electricity." The American Economic Review (2012):381-385.

[13] Boiteux, Marcel. "Peak-load pricing." The Journal of Business 33.2 (1960):157-179.

[14] Kahn, Alfred E. The Economics of Regulation: Principles and Institutions, Vol. 1. New York: John Wiley \& Sons, 1970.

[15] The Edison Foundation. Utility-Scale Smart Meter Deployments: Building Block of the Evolving Power Grid. Institute for Electric Innovation. Washington, D.C., 2014. Internet site: http://www.edisonfoundation.net/iei/Documents/IEI_SmartMeterUpdate_0914.pdf (Accessed April 10, 2015). 
[16] U.S. D. Electric Power Monthly with Data for October 2015. December 2015. Internet site: http ://www.eia.gov/electricity/monthly/pdf/epm.pdf (Accessed January 4, 2016)

[17] U.S. Department of Energy. Net Metering. Internet site: http://energy.gov/savings/netmetering-18 (Accessed MArch 4, 2016)

[18] Oklahoma Gas and Electric Company. Standard Rate Schedule:NEBO, 2012. Internet site: https://oge.com/wps/wcm/connect/2d66103a-b87d-49f8-b9baea4db9854800/70.10+NEBO.pdf?MOD=AJPERES\&CACHEID=2d66103a-b87d-49f8b9ba-ea4db9854800 (Accessed March 6, 2016).

[19] Brown, Ashley and Jillian Bunyan. "Valuation of Distributed Solar: A Qualitative View." The Electricity Journal 27.10 (2014):27-48.

[20] Oklahoma Secretary of State. Executive Department: Executive Order 2014-07.Internet site: https://www.documentcloud.org/documents/1146319-gov-mary-fallin-executive-order2014-07.html (Accessed March 4, 2016)

[21] Champion, Kathy. Oklahoma Corporation Commission. Personal Communication. January 6, 2016.

[22] Elhadidy, M. A. "Performance evaluation of hybrid (wind/solar/diesel) power systems." Renewable Energy 26.3 (2002): 401-413.

[23] Elkinton, Melissa R., Jon G. McGowan, and James F. Manwell. "Wind power systems for zero net energy housing in the United States." Renewable Energy 34.5 (2009):1270-1278.

[24] Darbali-Zamora, Rachid, Carlos J. Gómez-Méndez, and Andrés J. Díaz-Castillo. "Comparison of Residential Wind and Solar Energy Generation in the Island of Puerto Rico." Terrain 7: 4 (2015).

[25] Li, Chong, Xinfeng Ge, Yuan Zheng, Chang Xu, Yan Ren, Chenguang Song, and Chunxia Yang. "Techno-economic feasibility study of autonomous hybrid wind/PV/battery power system for a household in Urumqi, China." Energy 55 (2013): 263-272.

[26] Iqbal, M. T. "A feasibility study of a zero energy home in Newfoundland. "Renewable energy 29.2 (2004): 277-289.

[27] Grieser, Benno, Yasin Sunak, and Reinhard Madlener. "Economics of small wind turbines in urban settings: An empirical investigation for Germany." Renewable Energy 78 (2015): 334-350.

[28] Mostafaeipour, A., A. Sedaghat, A. A. Dehghan-Niri, and V. Kalantar. "Wind energy feasibility study for city of Shahrbabak in Iran." Renewable and Sustainable Energy Reviews 15, no. 6 (2011): 2545-2556.

[29] Dalabeeh, Ali S. Khraiwish. "Techno-economic analysis of wind power generation for selected locations in Jordan." Renewable Energy 101 (2017): 1369-1378.

[29] Dalabeeh, Ali S. Khraiwish. "Techno-economic analysis of wind power generation for selected locations in Jordan." Renewable Energy 101 (2017): 1369-1378.

[30] Baroudi, Jamal A., Venkata Dinavahi, and Andrew M. Knight. "A review of power converter topologies for wind generators." Renewable Energy 32.14 (2007): 2369-2385.

[31] Doye, Damona and Sahs, Roger. "Oklahoma Farm and Ranch Custom Rates, 20132014." Oklahoma Cooperative Extension Service, 2014. Internet site: http://pods.dasnr.okstate.edu/docushare/dsweb/Get/Document-6752/CR-205\%2020132014web.pdf (Accessed October 15, 2015). 
[32] Wilson, Eric, C. Engebrecht Metzger, S. Horowitz, and R. Hendron. 2014 Building America House Simulation Protocols. National Renewable Energy Laboratory; 2014. Internet site: http://www.nrel.gov/docs/fy14osti/60988.pdf (Accessed March 21, 2015).

[33] American Wind Energy Association (AWEA)-Small Wind Industry Standards. Internet site: http://www.awea.org/Issues/Content.aspx?ItemNumber=4638\&navItemNumber=727 (Accessed July 20, 2016)

[34] Small Wind Certification Council (SWCC)-SWCC Certified Turbines - Small: Compare Ratings. Internet site: http://smallwindcertification.org/certified-small-turbines/ (Accessed July 20, 2016)

[35] Vanderhoef, Eric. "Assessing the Viability of Residential Wind Energy in Michigan and the United States." M.S. Thesis, Michigan State University (2015).

[36] Bergey Windpower Company, Norman, Oklahoma. Personal Communication, July, 21, 2015.

[37] Staffell, Iain, and Richard Green. "How does wind farm performance decline with age?." Renewable energy 66 (2014): 775-786.

[38] Rademakers, L. W. M. M., H. Braam, and T. W. Verbruggen. "R\&D needs for O\&M of wind turbines." ECN Wind Energy, Tech. Rep. ECN-RX-03-045(2003).

[39] Small Wind Certification Council (SWCC)-SWCC Summary Report (Excel 10). $2015 a$. Internet site: http://smallwindcertification.org/wp-content/uploads/2015/12/SummaryReport-10-12-2015.pdf (Accessed January 3, 2016)

[40] Small Wind Certification Council (SWCC)-SWCC Summary Report (Excel 6). 2015b. Internet site: http://smallwindcertification.org/wp-content/uploads/2015/08/SummaryReport-10-11-2015.pdf (Accessed January 3, 2016)

[41] Addcox, Elizabeth, Sherri Schieffer, and Notie H. Lansford, Jr. Oklahoma Ad Valorem Mill Levies, Fiscal Year 2013, 2013. Internet Site:

http://rd.okstate.edu/resource/fiscal_year_2013.htm (Accessed September 15, 2015) 